Cómo citar este artículo / How to cite this article: Fernández-Pereiro, M. (2019). O recinto fortificado do Monte Aloia. Un xigante altomedieval esquecido. Lucentum, XXXVIII, 379-395. http://dx.doi.org/10.14198/LVCENTVM2019.38.18

\title{
O RECINTO FORTIFICADO DO MONTE ALOIA. UN XIGANTE ALTOMEDIEVAL ESQUECIDO
}

THE FORTIFIED SITE OF MONTE ALOIA. A FORGOTTEN GIANT FROM THE EARLY MEDIEVAL AGE

\author{
MARIO FERNÁNDEZ-PEREIRO \\ Universidade de Santiago de Compostela \\ mariofdezpereiro@gmail.com \\ https://orcid. org/0000-0002-7704-6088
}

Recepción: 30-05-2019

Aceptación: 08-08-2019

\section{Resumo}

No presente artigo, presentamos os resultados do estudo arqueolóxico realizado arredor dun dos maiores asentamentos fortificados localizados na Galiza. Malia ser un xacemento coñecido na historiografía, apenas foi obxecto dunha investigación arqueolóxica en profundidade. A maiores da caracterización morfolóxica e a análise arquitectónica, tamén se realizou unha recompilación de datos históricos. Ao longo deste texto, pretendemos aportar información inédita sobre este xacemento e, paralelamente, comezar a comprender a súa ocupación na época posromana, a través da comparación con algunhas das hipóteses historiográficas existentes para este momento histórico.

Palabras Chave. Gallaecia; arqueoloxía da Alta Idade Media; asentamentos fortificados; poboamento; reino suevo.

\section{Resumen}

En el presente artículo, presentamos los resultados del estudio arqueológico realizado alrededor de uno de los mayores asentamientos fortificados localizados en Galicia. Pese a ser un yacimiento conocido en la historiografía, apenas fue objeto de una investigación arqueológica en profundidad. A mayores de la caracterización morfológica y el análisis arquitectónico, también se realizó una recopilación de datos históricos. A lo largo de este texto

\begin{abstract}
In this paper, we present the results of the archaeological study of one of the largest hillfort occupations located in Galicia. Even though the site is well-known by academia, it has not yet been the object of thorough archaeological research. Apart from a morphological characterization and an architectural analysis, a collection of historical data is also presented. On this basis, we intend to provide unpublished information about this site, and thus to better understand the site in the context of post-Roman times through its comparison with some of the main historical hypothesis for this historical moment.
\end{abstract}

Key words. Gallaecia; Early Medieval Archaeology; fortified fettlements; fettlement pattern; Suevickingdom.

pretendemos aportar información inédita sobre este yacimiento, y paralelamente, comenzar a comprender su ocupación en época posromana, a través de la comparación con algunas de las principales hipótesis historiográficas existentes para este momento histórico.

Palabras Clave. Gallaecia; arqueología de la Alta Edad Media; asentamientos fortificados; poblamiento; reino suevo. 


\section{INTRODUCIÓN}

No alto do Monte Aloia localízase un dos asentamentos fortificados máis grandes, máis grande, e paralelamente máis descoñecido, do noroeste peninsular. Este xacemento apenas recibiu interese por parte da comunidade investigadora, apenas pequenas mencións inseridas en traballos máis xerais. Soamente un conxunto de breves intervencións arqueolóxicas realizadas a comezos do séc. XXI tiveron a oportunidade de aportar algo de información, perdéndose esta polos exiguos resultados e a falta de interese do equipo técnico a respecto da entrega das memorias de intervención arqueolóxica. Por mor disto moitas das cuestións que se pretendían resolver durante esa intervención ficaron.

Tanto este asentamento, coma outros documentados ao longo do noroeste peninsular, constitúe unha evidencia da reaparición da paisaxe fortificada tras a fin do imperio romano a comezos do séc. V e. c. Este fenómeno, malia ser un feito documentado noutros puntos da península (Gutiérrez González, 2014; Vigil-Escalera Guirado, 2015: 231-244; Vigil-Escalera Guirado e Tejerizo-García, 2014), foi debilmente tratado no pasado dentro da historiografía galega, comezando a ser obxecto de interese nos últimos anos (Fernández-Pereiro, 2018; Fernández-Pereiro et al., 2017; Sánchez-Pardo, 2012; Tejerizo-García et al., e.p.).

O presente traballo pretende superar a falta de información dispoñíbel sobre este gran recinto fortificado. Para isto, foron recompiladas todas as mencións localizadas nas fontes escritas coñecidas, dende a Idade media até o século XIX, aos que lle sumamos unha serie de datos obtidos a través da prospección superficial e dixital do xacemento por nós realizada. Isto permitiu realizar unha análise pormenorizada das características arquitectónicas e das solucións defensivas do sitio. Con todo, consideramos que se consegue unha visión en conxunto do asentamento, sendo posíbel realizar unhas primeiras hipóteses a respecto da súa inserción funcional e cronolóxica.

\section{LOCALIZACIÓN}

O Monte Aloia ${ }^{1}$ é a elevación que fecha pola súa parte meridional a Serra do Galiñeiro, sendo ao mesmo tempo o seu punto máis alto, cunha altura máxima de 634 m s. n. m. Esta zona da Serra está inserida dentro do Parque Natural Monte Aloia ${ }^{2}$, que conta con case 750 hectáreas, e que foi creado por Real Decreto no 4 de Decembro do 1978. O terreo do Monte Aloia está dividido entre as parroquias de San Bartolomeu de Rebordáns e a do Sagrario de Pazos de Reis. As dúas

1. As súas coordenadas ETRS89 son 526438 - 4659218.

2. Este é posterior ao Sitio Natural de Interés Nacional, creado no 5 de Xuño de 1935



Figura 1: Localización do Monte Aloia (Tui, Baixo Miño). (Figura realizada polo autor)

pertencen ao Concello de Tui, na comarca do Baixo Miño, tendo a segunda delas categoría de Entidade Local Menor. O Monte Aloia (Fig. 1) está situado ao noroeste da unión perpendicular de dúas vías de comunicación naturais, o río Miño e a Depresión Meridiana, que forman o val do Miño e o val da Louriña respectivamente. A súa elevada altura, e que a súa redonda sexa maioritariamente fondo de val, fai que o Monte Aloia sexa visíbel e identificábel dende calquera punto próximo.

O cumio do Monte Aloia ten unha orientación nordeste-suroeste e divídese en tres sectores diferenciados. O primeiro, situado nunha posición central, é o Coto do Santo. Este é unha gran masa granítica de ladeiras abruptas, leve orientación sueste-noroeste, cunha altura máxima de $634 \mathrm{~m}$ s.n.m. e que ocupa unha extensión aproximada dunhas 3 hectáreas. O segundo sector, situado na zona sur deste cumio central, consiste nun extenso rechán rodeado de varios afloramentos graníticos e que ocupa unha extensión aproximada dunhas 15 hectáreas. O terceiro dos espazos é unha valgada situada cara o noroeste, entre o Coto do Santo e o cumio que recibe o nome de Forno do Carbón ou Alto do Forno (Fig. 4). Esta valgada ten unha inclinación cara o leste e por ela discorre o regueiro Vilariño que alimenta ao río Deique. A extensión deste sector sería dunhas 14 hectáreas aproximadamente.

Malia a súa grande altura relativa, o Monte Aloia, en xeral, non conta cunhas ladeiras moi escarpadas. O que dificulta o ascenso ao cumio é o ascenso contínuo dende o fondo do val, que é onde discorren as vías de comunicación naturais. Neste punto, pola súa propia morfoloxía de rechán, é onde a inclinación das ladeiras se esaxera, sobre todo nas ladeiras sur e leste (Fig. 2).

Identifícanse dúas vías de acceso naturais ao cumio do Aloia. A primeira arrancaría dende o fondo do val e ascendería pola ladeira sur. Dende o punto inicial, a 

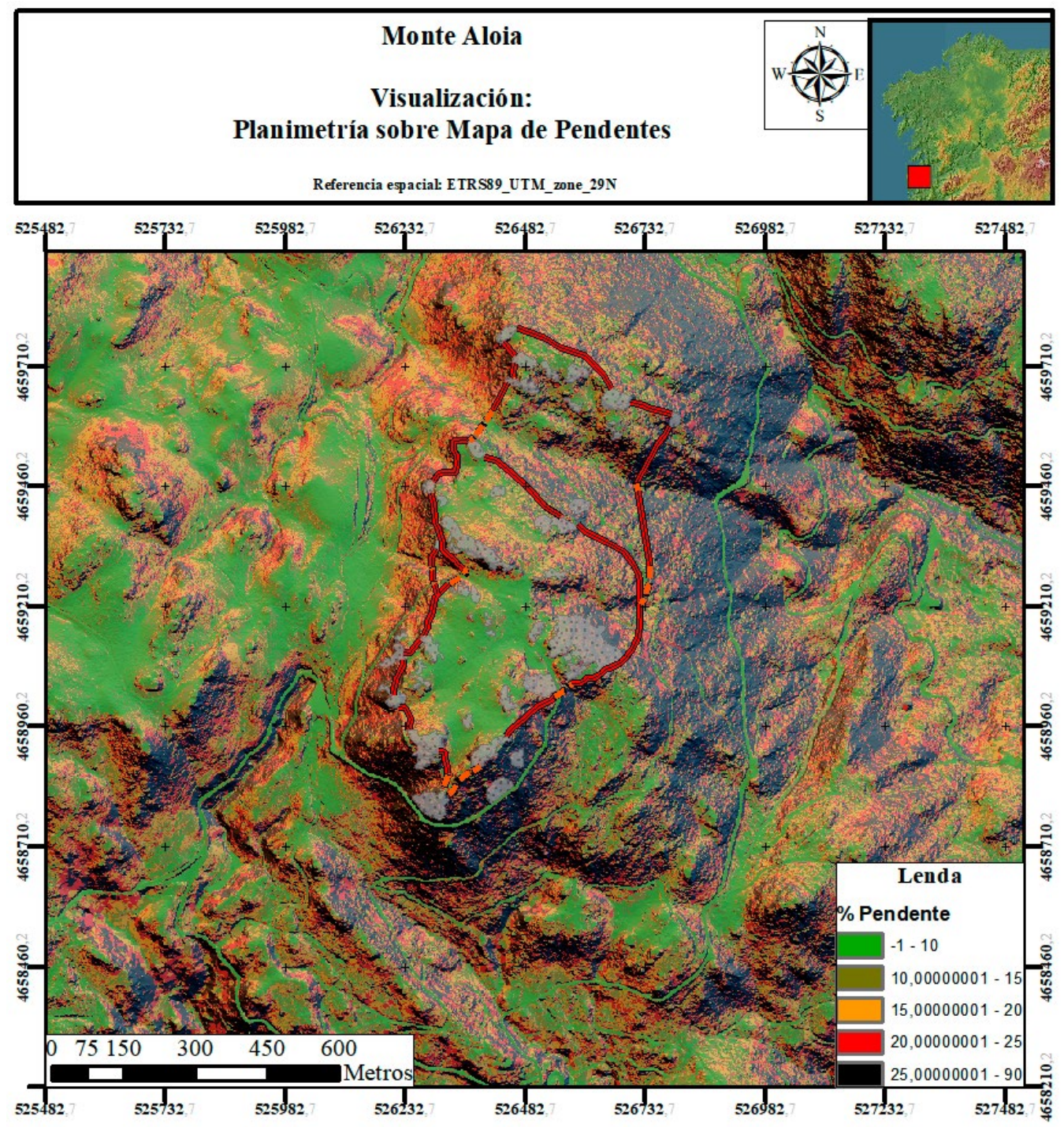

Figura 2: Mapa de Pendentes (slope map) do Monte Aloia. (Figura realizada polo autor)

igrexa parroquial de Rebordáns ${ }^{3}$, existe unha distancia duns oito quilómetros até unha valgada situada ao oeste do cumio do Aloia, ascendéndose dende os 18 m s.n.m. até uns 560 m s.n.m. A segunda vía de acceso provería dende o norte, a través da propia Serra do Galiñeiro. Neste caso o camiño descorrería pola xa mencionada valgada situada ao oeste do cumio, provindo dende o Val Miñor, ao noroeste do Aloia. Entendemos que esta vía de acceso puido influír na morfoloxía construtiva do recinto, sendo explicado na análise arquitectónica realizada a seguir no texto. Estas dúas vías de acceso, a que provén dende o Val do Miño ou dende o Val Miñor, conflúen na cara oeste do cumio do rechán. Dende este parten dúas vías de acceso ao interior do recinto

3. Citamos especificamente esta igrexa por estar situada no núcleo do aglomerado secundario romano identificado como Tude. Para ampliar información recomendamos revisar o traballo de Pérez Losada (2002: 71-72). fortificado. A primeira, máis moderna ${ }^{4}$, é unha estrada asfaltada que transcorre pola ladeira sur e que atravesa o recinto de leste a oeste, regresando ao punto de partida. A segunda vía de acceso é, posibelmente, a orixinal do recinto. Esta configúrase coma unha pequena ascensión desde o rechán a través dunha valgada con leve inclinación, que ascende dende o oeste até o leste e chega ao interior do recinto, ao pé do Coto do Santo, onde se situada a capela de San Xiao.

A vexetación da contorna varía entre o monte baixo e diferentes especies de arbóreas, sendo controlada polo persoal do Parque Natural. Esta vexetación procede da reforestación impulsada polo enxeñeiro foresta Rafael Areses nas primeiras décadas do séc. XX (Fig. 3). O uso actual do Monte Aloia varía dende o seu aproveitamento para o pastoreo de gando vacún en réxime de semiliberdade; para actividades de ocio, ca alteración

4. Na fotografía aérea coñecida comunmente como 'voo americano' (1956-57) non se atopaba construída. 


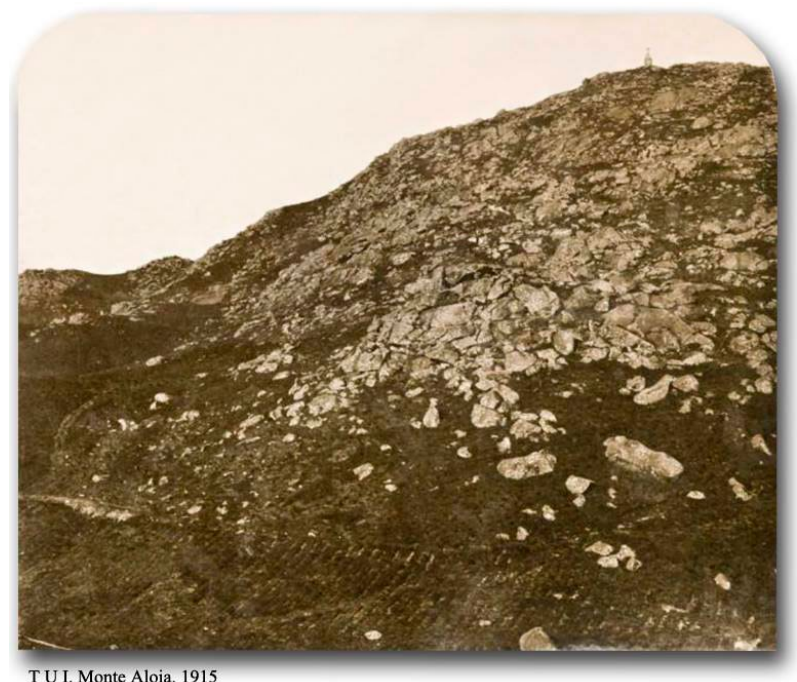

Figura 3: Fotografía das ladeiras do Aloia a comezos do séc. XX, antes do plan de reforestación do enxeñeiro Areses. [Fotografías antiguas de Tui, Monte Aloia (da colección de Babadiva), 16 de julio de 2015]. Recuperado de: https://www.facebook.com/fotosantiguastuy/photos/a.112148945624147/475586829280355/?type=3\&theater

de varios afloramentos para a súa transformación como miradoiros, a colocación de mesas de granito ou a construción de varios edificios (usados como cafetería etc.); até as actividades relixiosas, coa capela de San Xiao e un Vía Crucis construído a comezos do século XX.

\section{FONTES HISTÓRICAS E HISTORIOGRÁFICAS}

A existencia dun asentamento fortificado no cumio do Monte Aloia non pasou inadvertida ao longo da Historia, existindo referencias escritas sobre o lugar nos últimos dez séculos.

A referencia documental máis antiga a este gran asentamento aparece no documento polo cal os condes de Galiza, Urraca e Raimundo, delimitan o couto da cidade episcopal de Tui e doan os seus privilexios señoriais sobre este territorio ao bispado. Neste documento, datado no 1095 e. c., descríbense os límites do couto, aparecendo a seguinte mención: [...] et ad montem Aloyae, ubi fuit Civitas antiquitus condita, et ubis sunt reliquiae S. Juliani repositae [...] (Galindo Romero, 1923). Malia ser unha mención moi parcial e casual debido ao obxectivo do documento, é de interese a puntualización que se inclúe sobre o Monte Aloia, xa que é unha excepción no texto, sendo o resto unha sucesión de topónimos para marcar os límites do couto. Pola forma de describir o lugar, enténdese que o asentamento fortificado do Aloia estaba abandonado, debido a súa antiquitus condita e, posibelmente, soamente servía como recinto para marcar o terreo sagrado da capela de San Xiao. A mención 'especial' que ten na redacción pódese supor en base a importancia simbólica desta posíbel función ou polo papel desenvolvido polo Aloia, denominado no privilexio como civitas, no pasado.
Este uso de asentamentos fortificados como elementos simbólicos e referenciais na paisaxe xa é apuntando para outros casos no noroeste peninsular (Lixó Gómez, 2018: 50-57; Sánchez-Pardo, 2010a: 132).

A seguinte mención, por orde cronolóxica, provén de Prudencio Sandoval. Este, bispo de Tui entre 1608 e 1612, no seu libro titulado Antigvedad dela civdad, $y$ iglesia cathedral de Tvy, y de los obispos qve se save aya auido en ella realiza a seguinte descrición do recinto do Monte Aloia, sendo escrito o topónimo como Alhoya ou Hoya:

En lo alto desta sierra, que es vna gran legua, de muy aspero camino de Tuy, està hun sitio no muy llano, con vna cerca de media legua en contorno, que tendra de grueso el muro mas de tres varas: tiene a cierta distancia sus Cubos, o Rebellines, vense claramente por donde eran las puertas, y entrada, y que todo era fortissimo. Aqui dicen vbo vna gran ciudad, y se halla cimientos de casas, y edificios, y en medio està vna hermita dedicada al martyr San Iulan [...] Es (a mi parecer) vn castro, o sitio fuerte, que ay mucho en Galicia, los quales hacian los christianos para recogerse en ellos, con sus mugeres, y hijos, ropa, defenderse el tiempo que moros, y corsarios corrian la tierra, y aqui con solas piedras podrían defenderse de infinitos inemigos, y no podia ser sitiados, ni combatidos [...] Fue (a my parecer) la principal ciudad de las montañas de Galicia (Sandoval, 1610: folios 5-7).

Na primeira das mencións Sandoval fai unha breve descrición do asentamento fortificado do Aloia. As medidas dadas tanto do ancho dos muros coma do contorno do asentamento fortificado son moi similares ás medidas documentadas durante o traballo de prospección arqueolóxica ${ }^{5}$. Paralelamente, as referencias a estruturas presentes no sistema defensivo son moi interesantes. A mención aos cubos, posibelmente, fai referencia á existencia de torres defensivas situadas intermitentemente polo perímetros defensivo do asentamento. Os revelíns (Blanco-Rotea, 2015: 286), que é un termo aparecido na arquitectura militar do séc. XVI, pode facer referencia á barbacá localizada na entrada principal do sistema defensivo. A diferenza entre portas e entrada pode indicar a existencia de varios postigos auxiliares desta entrada principal fortificada coa barbacá. Noutro libro do mesmo autor, coñecido comunmente como Historias de cinco Obispos, aparece a seguinte mención: [...] hallé en una Hermita Antiquissima de S. Iulian que está en un monte, donde dizen, fue la antigua Tvy, [...] (Sandoval, 1615: 166).

5. Unha legua castellana varía entre os 4190 metros (da legua antiga) até os 5572,7 metros (da legua vulgar, imposta por Filipe II no 1568). Media legua variaría, entón, entre os 2095 metros e os 2786,35 metros, sendo o perímetro aproximado do asentamento fortificado do Monte Aloia duns 2700 metros. Unha vara castellana mide $0,83 \mathrm{~m}$, que multiplicado por $3 \mathrm{da}$ unha medida de 2,61 m. Esta medida é moi similar ao ancho medio das murallas, que varía entre os $2,5 \mathrm{~m}$ até os 4 metros. 
A mención á capela de San Xiao é repetida nos dous textos, ao igual que a hipótese de que alí era onde se situaba unha cidade, entendendo que tal cousa se debe á existencia dunha boa cantidade de edificios. Sandoval é quen de realizar unha hipótese funcional e cronolóxica, considerando que o Aloia serviría como un lugar de reunión e concentración das poboacións circundantes cando existía algún conflito bélico, mencionando ataques musulmáns ou de corsarios. Tanto os primeiros coma os segundos, que ben poderían ser ataques viquingos (Sánchez-Pardo, 2010b), remítenos aos séc. VIII-X e. c., a non ser que Sandoval mencione estes ataques coma unha referencia simbólica xeral.

[...] a poblarse legua de muy aspero camino, donde oy está, en un sitio no muy llano, que se llamó Cabeza de Francos, con una cerca de media legua en contorno, y de grueso más de tres varas; y según la fortaleza de aquellos tiempos, tiene à cierta distancia sus Cubos, y Rebellines. Este sitio ocuparon los primeros Moradores de Tuy, mientras aquella Ciudad fué Frontera de los Moros, y despues mudaron su habitación donde oy la tienen sobre las Aguas de el Miño (Huerta y Vega, 1733: 263).

De la Huerta y Vega, aproveitando o seu cargo de Cronista do Reino da Galiza, publicará, máis dun século despois de Sandoval, os Anales de el Reyno de Galicia. Nel describe un asentamento fortificado próximo a Tui, denominado Cabeza de Francos ${ }^{6}$. Exceptuando o diferente topónimo, a descrición recorda en grande medida á de Sandoval. De la Huerta apunta a que sería no séc. VIII e. c. o momento cronolóxico da ocupación do Monte Aloia, identificándoo como o solar da cidade de Tui antes do seu traslado ao seu actual emprazamento.

Entran los bárbaros en España, vienen los suevos a Galicia donde se establecen, noticia de lo que sufrió con ellos Tuy y su tierra, fundan los de esta ciudad una nueva población en el monte Aloya, y otras memorias de aquella época. [...] Al punto que los suevos con su rey Hermenexico se vieron libres de los vándalos empezaron a esparcirse por Galicia robando, talando y cometiendo otros muchos daños y estorsiones en la Provincia sin tener posicion por entonces, $y$ aun porcion de años despues del terreno que les tocó por suerte á causa de la resistencia grande que le hacían los naturales del país como dice el M. Flórez, manteniendo estos con valor y constancia las fortalezas de las que estaban apoderados, y obligando muchas veces a los suevos a tratados de paz: [...] Los Ciudadanos de Tuy, y habitantes de su inmediacion, viendo la frecuencia con que eran acometidos de los suevos, y que nada tenian seguro con ellos, trataron de hacer una fortificacion fuerte y segura en donde se pudiesen resguardar con sus

6. Existe un asentamento fortificado da Idade do Ferro, nun lugar próximo ao Monte Aloia, coñecido como castro de Cabeza de Francos ou Alto dos Cubos, polo tanto de aquí pode vir a confusión co topónimo. mugeres, familia, ganados e intereses, y defenderse en tiempo de invasiones y hostilidades barbaras: $y$ al efecto se fueron a la cumbre del monte Aloya, distante de Tuy una legua de muy malo, aspero y fragoso camino, y alli en su mayor altura levantaron una nueva poblacion con suficientes casas y edificios para el indicado fin: y para su defensa y seguridad la cercaron en redondo con una fuerte y gruesa muralla de media legua en circunferencia; [...] Cuyo sitio sirvió de asilo y refugio a los tudenses y circunvecinos por dilatados años, y mientras este país fue infestado de piratas y gente enemiga. De esta poblacion en la referida montaña aun hoy en dia, a pesar de tantos siglos como han transcurrido, se hallan bestigios [...] Es tradicion constante en este país que la indicada muralla y casas se hicieronalli para refugio de los habitantes de nuestro pueblo y sus contornos cuando la ciudad era acometida de naciones enemigas y piratas (Ávila y La Cueva, 1995: cap. V).

No 1852, Ávila y La Cueva publica a súa obra Historia civil y eclesiástica de la ciudad de Tuy y su obispado. No capítulo V relata sobre a chegada dos continxentes bárbaros á Gallaecia no séc. V e. c. Neste fragmento transcrito, Ávila describe a conflitividade existente no momento, seguramente a partir doutras obras previas coma a Crónica de Idacio de Chaves (López Silva, 2004), por exemplo. A partir desta conflitividade crea un discurso sobre o momento de ocupación e a funcionalidade do recinto fortificado do Monte Aloia, considerando que este foi realizada polos habitantes de Tui para defenderse dos saqueos do continxente suevo.

Para rematar esta serie de mencións históricas sobre esta fortaleza, Murguía fai tamén mención sobre a existencia do recinto castramentado del Alhoya. Baseándose na descrición de Sandoval, relaciona esta fortificación ca época da presenza sueva no noroeste peninsular (Martínez Murguía, 1888: 761-763, 802).

Será a partir do comezo do séc. XX cando comecen os traballos de campo, de sorte dispar, no recinto do Aloia. A primeira das intervencións das que se ten coñecemento realizouse antes do ano 1947, xa que é nesta data cando se publica un artigo titulado El monte Medulio ¿Es el Monte Aloya? na revista Construcciones. Revista de la Federación Nacional de Aparejadores (Fernández Costas, 1947). Malia a imposibilidade actual de consultar esta publicación, é posíbel coñecer parte do contido grazas á que é citada a posteriori por Garrido. Este menciona unha serie de sondaxes realizadas [por Fernández Costas, entendemos] en varios puntos, na que se exhumaron fragmentos de tegulae y otros restos de «cerámica tosca castrexa» (Garrido Rodríguez, 1987: 14-27). Garrido, dentro do seu libro sobre as fortificacións situadas dentro da diocese de Tui, inclúe unha ampla descrición e unha planimetría detallada procedente do seu propio traballo de campo. Nun artigo posterior amplía algo de información sobre a súa interpretación, mais sen apenas aportar máis datos empíricos dos xa coñecidos (Garrido Rodríguez, 2010). 


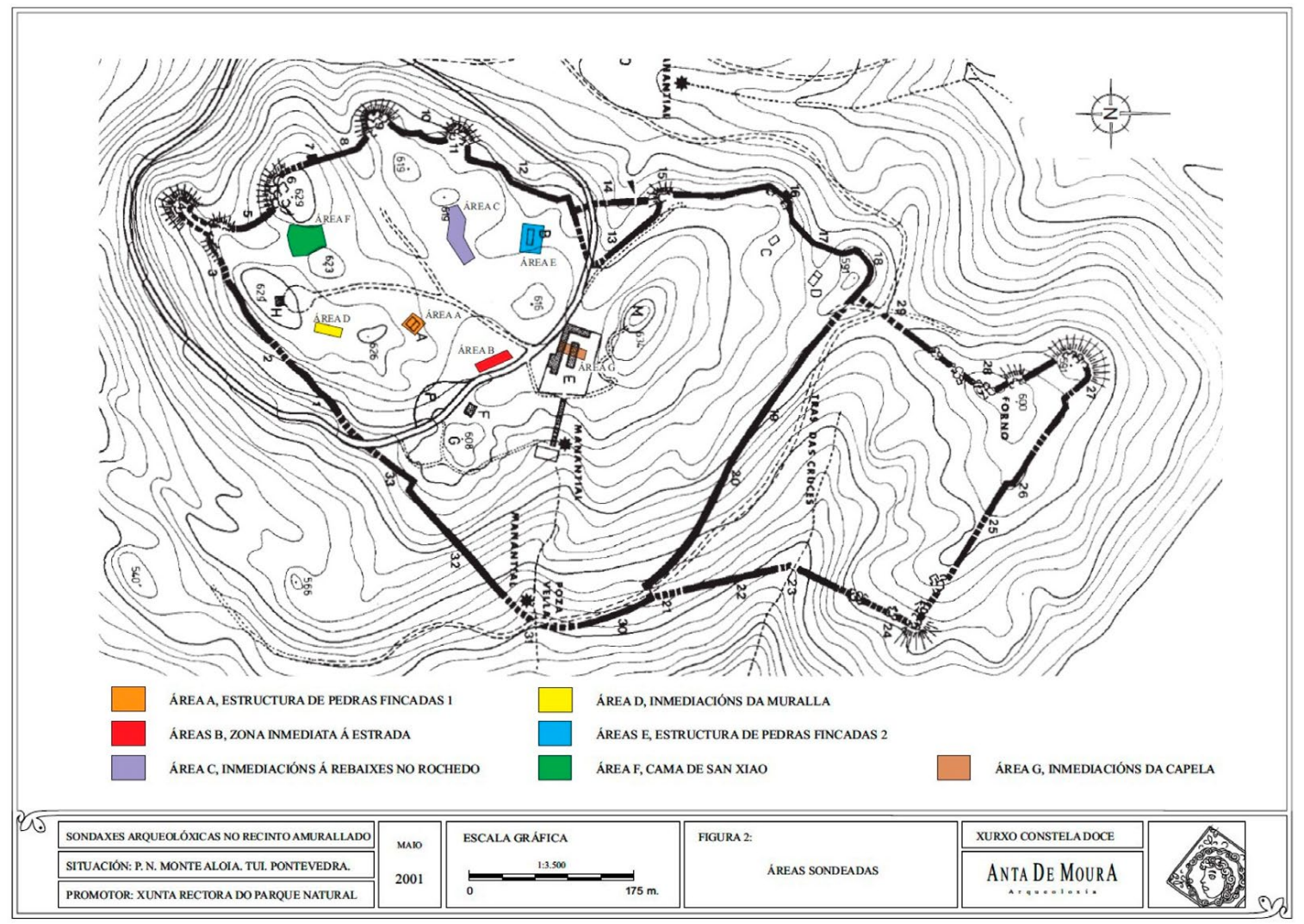

Figura 4: Plano do Monte Aloia onde se localizan as sondaxes realizadas no ano 2001. Cedido por J. J. Perles Fontao a partir da planimetría orixinal de Garrido (1987)

No ano 2001, promovido pola Xunta Reitora do Parque Natural Monte Aloia, realízanse unha serie de intervencións arqueolóxicas no Aloia coa intención de realizar a posta en valor dos recursos arqueolóxicos que forman parte do parque natural do Monte Aloia (Constela Doce, 2001). Foron realizadas catro intervencións no recinto do Monte Aloia (Constela Doce, 2001; Prieto Robles, 2001; Torres Bravo, 2001b; 2001a), cun total de $287,4 \mathrm{~m}^{2}$ escavados (Fig. 4). Destas catro intervencións só é posíbel consultar os informes valorativos, polo que os datos dispoñíbeis son bastante reducidos. Malia esta situación, entendemos que é interesante realizar unha valoración destas intervencións. Nestas intervencións escavouse dúas zonas diferenciadas: un tramo do sistema defensivo e unha serie de sondaxes no interior do recinto sur.

A sondaxe realizada no sistema defensiva sitúase na zona occidental, xusto no punto onde a barbacá anexa á muralla principal. Nesta intervención caracterizouse a muralla principal, cunha altura media conservada de 1,2 metros e un ancho medio próximo aos 3,5 metros, e a muralla secundaria, cunha altura media conservada de 1,5 metros e un ancho medio de 1,5 metros. Malia a diferenza de tamaño, as tipoloxías construtivas son similares.

A extensión da zona escavada no interior do recinto do Monte Aloia ascende a 95,40 $\mathrm{m}^{2}$, repartidos en 7 sondaxes. Varios factores dificultaron a intervención e a identificación dos diferentes estratos: a pouca potencia do terreo, o asolagamento do mesmo durante as chuvias, as raíces da masa arbórea e o arrasado do xacemento. Nas áreas A e E localizáronse estruturas semellantes, con muros de cachote a seco construídos a soga e tizón, compostos de dúas caras e recheo interno. Foi localizada tegula en anacos reutilizadas coma cuñas, e nunca un caso claro de derrube (Constela Doce, 2001: 11). Na área B localizouse unha estrutura alongada de $9 \mathrm{~m}$ de lonxitude e, malia a aparición de tegulae en superficie, as sondaxes deron como resultado que había grandes buratos enchidos con lixo moderno [sic], polo que o contexto estaba completamente alterado. A área $\mathrm{F}$ sitúase nas proximidades da Cama de San Xiao, localizándose evidencias de muros e ocos de poste e un grande derrube de tegulae próximo á propia pedra. $\mathrm{Na}$ área $\mathrm{G}$ localízanse as sondaxes realizadas nas proximidades da ermida de San Xiao. Nunha delas localizouse a cimentación do actual edificio relixioso, unha construción anterior non identificada e por baixo, un nivel cheo de restos de tegula anterior a dita construción (Constela Doce, 2001: 14). As áreas C e D deron resultados negativos, malia a aparición a nivel superficial de tegulae. En todas as sondaxes foi repetitiva a ausencia significativa de restos materiais móbeis, máis alá dunha moeda de vellón (séc. XVII) e uns fragmentos cerámicos asociados á estrutura situada baixo da ermida.

Sánchez-Pardo inclúe unha descrición do recinto do Aloia nunha revisión sobre as fortificación galegas 
ao longo da Alta Idade Media (Sánchez-Pardo, 2012), apuntando que as evidencias materiais e a advocación a San Xiao (advocación tardoantigua característica en Galicia [sic] $)^{7}$ poderían indicar unha cronoloxía de ocupación nos momentos posteriores á fin do estado romano na Gallaecia. Tamén entende a existencia deste asentamento coma un verdadero poblado que en algún momento llegaron a agrupar a la población de su entorno y que, además, funcionaron como centros administrativos y de jerarquización social (Sánchez-Pardo, 2012: 38), na liña do xa apuntando por Castellanos García (2006).

Outras investigadoras tamén se toparon, de forma transversal, co recinto do Aloia. Blanco-Rotea menciona este recinto dentro dun traballo máis xeral sobre as fortificacións na zona do Baixo Miño (Blanco-Rotea, 2013). Currás Refojos inclúe á fortaleza do Aloia como un recinto de cronoloxía indeterminada dentro do seu traballo de investigación predoutoral sobre a paisaxe fortificada protohistórica no Baixo Miño (Currás Refojos, 2015: 886-892). Para rematar, é interesante mencionar o gran traballo de Gago Mariño coa divulgación do recinto do Aloia, e do patrimonio arqueolóxico galego, a través do seu blogue Capitulo Cero (Gago Mariño, 2010a; 2010b).

\section{O RECINTO FORTIFICADO DO MONTE ALOIA}

O asentamento fortificado situado no cumio Monte Aloia confórmase como un dos máis grandes da Gallaecia, alcanzando a súa extensión, aproximadamente, ás 32 hectáreas. A súa planta ten unha orientación suroeste-nordeste e divídese en dous recintos anexos e de diferente tamaño, o maior ao sur e o menor ao norte. Exceptuando sectores puntuais, o perímetro defensivo do Monte Aloia encóntrase conservado na súa totalidade (Fig. 5). Os maiores culpábeis de alteracións son a acción antrópica directa, como lugar de ocio e/ou relixiosidade, e a repoboación forestal, iniciada a principios do séc. XX polo enxeñeiro Areces, pola presión antrópica e vexetal que exercen sobre a contorna. Posibelmente a designación como Parque Natural -Decembro do 1978- e o culto relixioso favoreceron a conservación do perímetro defensivo. A situación intramuros é diferente. Neste punto a presión antrópica realizada no último século é moito maior. As construcións, o asfaltado do acceso ás proximidades da capela, as intervencións nos afloramentos graníticos -agora denominados miradoiros-,

\footnotetext{
7. Esta referencia ten que ser tomada en consideración xunto ca mención da existencia de reliquias do Santo. Isto podería indicar unha importancia do lugar fortificado en base ao seu valor simbólico, ou que, debido á relevancia do asentamento, este fora escollido para gardar as reliquias, aumentando a categoría do Aloia.
}

as grellas, mesas e bancos de pedra, a utilización de pedras -seguramente retiradas dalgunha construción do recinto- para marcar os camiños internos, a presenza de visitantes continuamente etc., alteraron e alteran en gran medida o interior.

A escolla do Monte Aloia para a construción dun asentamento fortificado non é casual. A maiores do custoso do acceso dende o fondo do val, dende o alto do Aloia obtense un amplo control visual sobre toda a contorna (Fig. 6), sendo identificábeis os vales próximos, o da Louriña ao leste e o do Miño ao sur; a serra da Groba, o Val Miñor e a ría de Baiona ao oeste; ou as Illas Cíes e a bocana da ría de Vigo, a máis de 20 quilómetros ao norte. Excepcionalmente, se as condicións climáticas así o permiten, tamén se observan puntos moi característicos, como pode ser a desembocadura do río Miño e castro de Santa Tegra ao Oeste; os altos da serra do Faro de Avión ao leste; ou as bocanas das Rías Baixas ao norte. A maiores desta visibilidade xeral, os diferentes afloramentos localizados no sistema defensivo teñen, a súa vez, un control visual próximo dos sectores cara os que están enfocados.

O recinto de maior tamaño, entendido como o principal dentro do asentamento, engloba o Coto do Santo e todo o rechán situado ao sur deste, ocupando algo máis de 20 hectáreas, alcanzando case os dous terzos da superficie total ocupada pola fortificación. A liña da muralla rodea polas ladeiras sur e oeste o rechán e o Coto do Santo pola súa ladeira norte, sempre aproveitando o relevo e os afloramentos graníticos para o apoio dos lenzos de muralla, como xa indicara Garrido (1987: 21), fechando o maior espazo posíbel a cambio do mínimo esforzo construtivo. En cambio, no sector leste o trazado apartase desta lóxica construtiva e sobreesténdese ladeira abaixo, co fin de incluír intramuros unha fonte de auga, a coñecida coma Poza Vella. No espazo acoutado por este recinto é onde se sitúan as estruturas intervidas no ano 2001, non sendo actualmente visíbeis en superficie

A valgada occidental antes descrita parece o punto orixinal de entrada a este recinto. Esta hipótese parte tanto pola morfoloxía do lugar, como pola construción dunha muralla que reforza este lugar. Mentres que a muralla principal rodea a valgada pola súa parte superior e continúa o seu trazado, este segundo lenzo atravésaa en liña recta, conformando un espazo triangular no medio dos dous trazados. Polo tanto, entendemos que esta segunda muralla está construída como reforzo do propio sistema defensivo da entrada. Garrido indica na súa planimetría (Fig. 4) unha posíbel segunda entrada, entendendo esta coma un portelo, na zona suroeste deste recinto principal, aproveitando igualmente unha pequena valgada situada entre dous grandes afloramentos. Esta zona é de difícil acceso na actualidade por mor da vexetación.

O segundo recinto ten unha forma irregular trapezoidal, anexándose pola zona nordeste ao primeiro. A súa superficie ocupa aproximadamente unhas 12 ha. A 




Figura 5: Planimetría do Asentamento fortificado do Monte Aloia. (Figura do autor)

lóxica ${ }^{8}$ induce a pensar que foi construído ca finalidade de fortificar a Pedra do Acordo e ter controlado o acceso ao recinto que provén do norte a través da dorsal. $\mathrm{Na}$ metade occidental e setentrional, continúa a lóxica construtiva do primeiro recinto e o seu trazado está adaptado ao terreo, partindo dun afloramento granítico no que o primeiro recinto fai esquina até rodear a Pedra

\footnotetext{
8. A vexetación e a acumulación de terra tapa os puntos onde se xunta esta muralla norte co recinto sur, impedindo documentar se imbrican ou anexan.
}

do Acordo e continuar dirección leste. Aquí, ao xirar dirección sur para unirse de novo ao recinto principal, o trazado descende de cota e atravesan novamente outra valgada, deixando intramuros o nacemento do regueiro Vilariño.

Intramuros do recinto fortificado do Aloia conserváronse evidencias de varias estruturas, sendo algunhas delas escavadas na intervención do ano 2001. Nas áreas A, B e E apareceron evidencias de estruturas mais os resultados non foron concluíntes, ao non aparecer ningún material móbel que aportara información a respecto da súa cronoloxía. Tamén se escavou unha 

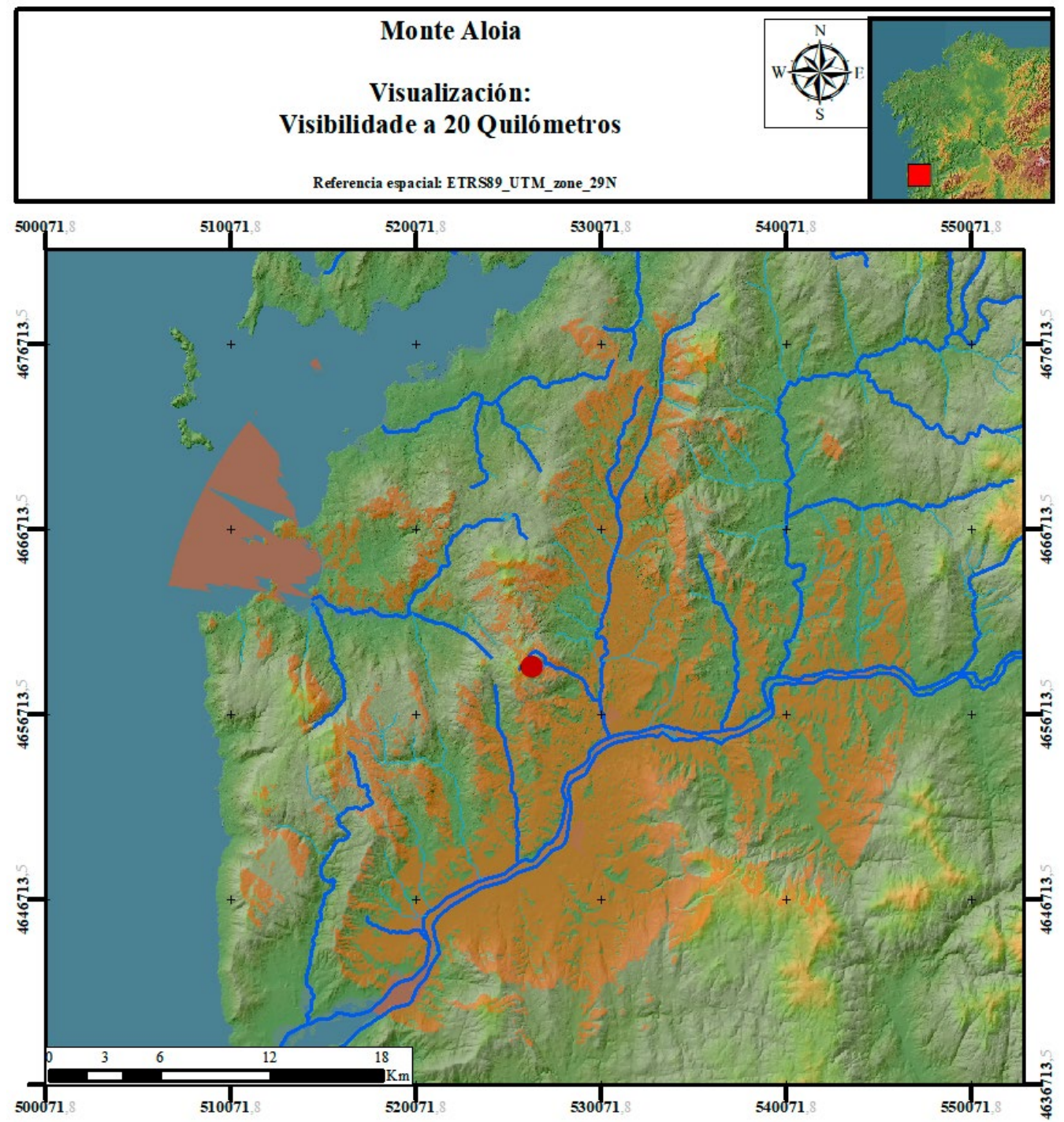

Figura 6: Control visual do Asentamento fortificado do Monte Aloia. (Figura realizada polo autor)

zona anexa ao bolo granítico coñecido como Cama de San Xiao (Fig. 7) ${ }^{9}$, aparecendo evidencias, segundo os datos descritos no informe, de que nalgún momento alí existiu unha estrutura de madeira teitada con tegulae (área F):

[...] nunha das catas realizadas pegada ó batolito apareceu un derrube de tégulas moi potente. O seu estado de conservación é moi malo, pois as tégulas, agás algún fragmento de imbrice na parte máis baixa do derrube, aparecen esnaquizadas por completo, amosando un grado de fragmentación inusual. A acción de pisado arredor da rocha sería a causa deste grado de destrucción. Noutra das sondaxes situada fronte a ornacina apareceron restos de derrube (máis

9. Existe todo un ritual relacionado con este bolo granítico. Para máis información: Galicia Encantada, Cama de san Xulián (Xiao) no Monte Aloia. Mitos, lendas e contos galegos. Recuperado de: https://galiciaencantada.com/lenda. asp? cat $=18 \mathrm{eid}=2413$ escasos que na outra cata) e por debaixo deles, dous ocos de poste de forma circular, escavados na rocha granítica, e con cuñas de granito nas paredes. Os derrubos aparecen por riba dun solo natural [...] Semella que nos atopamos ante unha cubrición a unha ou dúas augas, de xeito aberto, por non se atoparon restos de paredes de pedra nin derrubes dos $\operatorname{mesmos}^{10}$.

Por último, tamén se escavou nas proximidades da Capela de San Xiao (área G). O actual edificio é do s. XVIII, como xa indica Sandoval: [...] vna hermita dedicada al maryr San Iulan, no es muy antigo el edificio [...] (1610, Folio 5-6), mais está construído sobre outro anterior, feito que se confirma tanto polas fontes documentais (Martínez Sigüenza, 2003: 13) coma polas arqueolóxicas (Constela Doce, 2001: 14). Este edificio

10. Incluímos a transcrición da referencia a esta estrutura aberta teitada de tegulae porque nos pareceu moi singular (Constela Doce, 2001: 13). 


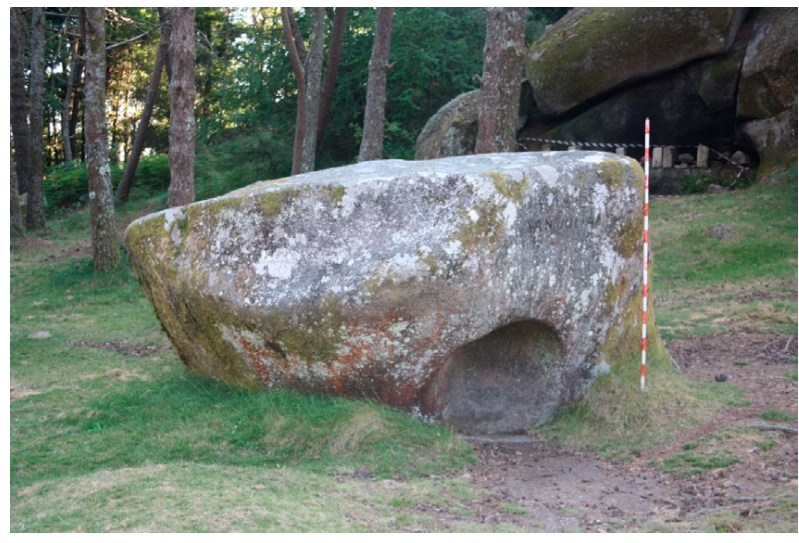

Figura 7: Cama de San Xiao. (Fotografía do autor)

previo ao actual estaría relacionado, igualmente, cun derrubo de tegulae.

\section{ANÁLISE ARQUITECTÓNICA}

Do mesmo modo que a escolla do lugar para a construción do asentamento fortificado do Aloia non é casual, a planta do mesmo ou as diferentes solucións arquitectónicas parciais tampouco o son. Seis son os elementos arquitectónicos máis representativos do recinto do Aloia: o tipo de fábrica, o uso dos afloramentos graníticos, a súa planta única, a variación zonal no esforzo defensivo, a barbacá que reforza a entrada e, por último, a tipoloxía das estruturas interiores.

Aún cuando es variado el aparejo de los muros, existen unas características comunes en toda la longitud de los mismos. Una de ellas son los grandes bloques de piedras hincados para formar la base del muro, $e$ incluso otros sueltos que le proporcionan un carácter ciclópeo, aunque de forma aislada y sin continuidad (Garrido Rodríguez, 1987: 23).

A fábrica construtiva das murallas do Aloia semella similar e constante ao longo de todo o sistema defensivo, caracterizándose coma unha muralla de dobre paramento con recheo interior de pedregullo e terra, trabados con tizóns. Distínguese un uso combinado de perpiaños irregulares e de cachotaría, onde os primeiros estarían localizados contra a parte inferior, asegurando a estabilidade e fortaleza da construción, alcanzando a altura requirida por medio de fiadas de cachotaría concertada (Fig. 8). O material pétreo empregado esta lixeiramente traballado, procurando só carear a parte exterior e sen buscar unhas formas regulares. As fiadas son tendentes a unha disposición regular, adaptándose ao terreo. Existen zonas onde este material pétreo traballado combínase con perpiaños, empregados principalmente como cimentación dos lenzos. Esta fábrica pode ter variantes sectoriais, dependendo da facilidade para obtención do material ou da necesidade construtiva, modificándose a proporción dos perpiaños presentes. Igualmente, na anchura das murallas tamén se rexistran variábeis sectoriais. No recinto sur documéntanse variacións entre os $2,40 \mathrm{~m}$ e os case $4 \mathrm{~m}$, mentres que no recinto norte se conservan anchuras entre os 2 e $3 \mathrm{~m}$. En ningún dos sectores do sistema defensivo se conserva a altura orixinal dos lenzos, alcánzanse, nas zonas mellor conservadas, alturas de até $3 \mathrm{~m}$. Parece que toda a muralla está construída a seco, xa que non se localizan restos de argamasa entre o material pétreo que as conforma nin é mencionado nos informes das intervencións arqueolóxicas.

O sistema defensivo do recinto, malia artificializar o cumio do Aloia, incorpora ao seu trazado unha boa cantidade de elementos naturais, tanto para un uso pasivo como activo. Isto obsérvase, fundamentalmente, na utilización dos afloramentos graníticos. Por norma xeral, estes serán aproveitados de modo pasivo para o seu uso como cimentación ou como punto de apoio, inicial ou final, dos tramos de muralla, reforzando estruturalmente o sistema defensivo. A maiores desta escolla por motivos arquitectónicos, e en vista do seu uso actual como miradoiros, pódese considerar o uso activo destes afloramentos a modo de torres naturais, xa non só pola fortaleza defensiva dos mesmos, senón polo control visual directo do sector onde se sitúan. Esta última hipótese xa é mencionada por Garrido: [...] los picachos o peñascos elevados y a utilizarlos a modo de vigilantes y defensivos torreones (1987: 21). O mesmo autor fala da existencia de dúas posíbeis torres anexas á muralla (Garrido, 1987: 23), situadas as dúas no recinto principal, unha na zona suroeste e a outra na noroeste, coincidindo ca descrición de Sandoval, que referencia a existencia de cubos. Estas non foron localizadas durante a prospección por mor do actual estado de conservación do xacemento. A posíbel existencia de torres construídas entre as naturais indica unha intencionalidade de reforzar esa vontade defensiva, fundamentalmente no sector occidental, xa que é o máis próximo á valgada occidental onde conflúen as vías naturais de acceso.

A diferenza doutros recintos fortificados similares coñecidos que están configurados en base a un só recinto ou varios concéntricos, como pode ser o caso do Castro Valente (Fernández Abella, 2014), Faro de Budiño (Fernández-Pereiro, 2016) ou varios exemplos coñecidos para o val do Sil (Fernández-Pereiro et al., 2017); o sistema defensivo do Monte Aloia é unha excepción tipolóxica xa que posúe un recinto principal e outro anexo. O primeiro é, por lóxica, o de maior tamaño e parece ter un obxectivo claro, xa que fecha a superficie que parece máis favorábel para o estabelecemento de estruturas habitacionais, de almacenamento ou, incluso, cultuais ${ }^{11}$. O recinto anexo ten unha función diferente aos anexos coñecidos para os recintos fortificados prehistóricos, coñecidos como antecastros. Estes,

11. Incluímos a transcrición da referencia a esta estrutura aberta teitada de tegulae porque nos parece moi singular (Constela Doce, 2001: 13). 

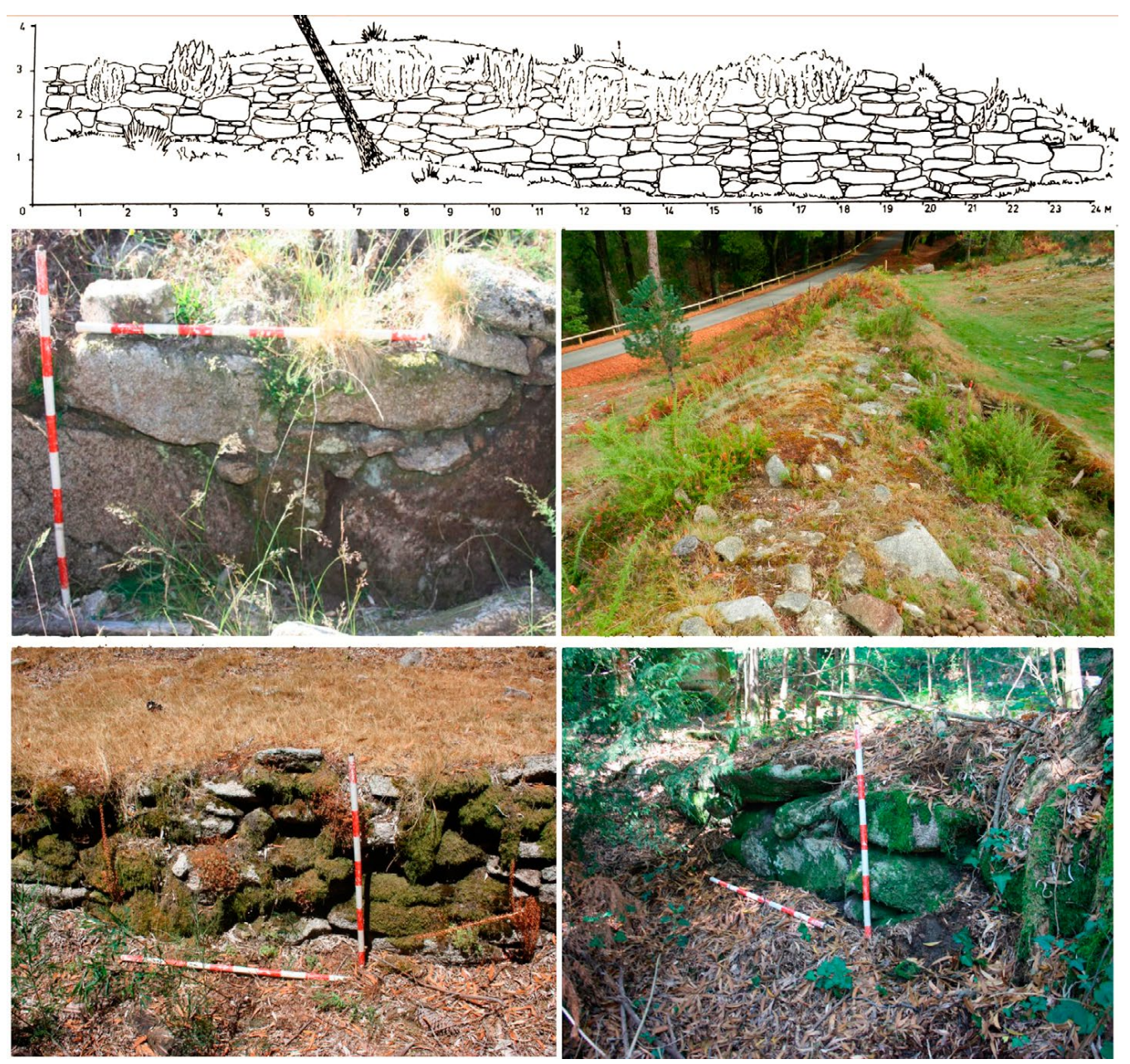

Figura 8: Arriba, alzado dun lenzo murario debuxado por Garrido (1987: 20). Abaixo, fotografias de varios puntos do sistema defensivo que mostran a técnica construtiva e o estado actual de conservación. (Fotografías do autor)

por norma xeral, sitúanse nas zonas de acceso ao recinto principal, non sendo esta intención interpretada para o recinto anexo do Aloia. Neste caso, este recinto anexo engloba unha superficie agreste, principalmente unha valgada, e non parece ser tan favorábel para a construción de estruturas habitacionais. Entendemos que este segundo recinto é a representación arquitectónica dunha segunda fase construtiva tras o remate, ou nun estado de construción moi avanzado, do recinto principal. Malia isto, tamén consideramos que esta segunda fase non se desenvolvería nun momento moi separado no tempo, debido ao similar da fábrica das estruturas.

Polo tanto, que valor arquitectónico ten a construción deste anexo de 12 ha?

Entendemos que dous intereses complementarios poden responder este interrogante. Por un lado, a necesidade de reforzar unha posición de fortaleza defensiva. A construción do recinto setentrional permite incluír dentro do recinto amurallado o Alto do Forno (ver fig. 4). Isto permite reforzar a defensa desta zona, xa que a ladeira norte do Coto é pouco escarpada, e, de forma paralela, afianzar o control efectivo da vía de acceso provinte dende a dorsal. Pola outra banda, de forma paralela, a construción deste recinto permite incluír intramuros unha fonte de auga importante, o xa mencionado regueiro Vilariño. Este podería facilitar a posibilidade de que nesta zona existira unha zona de produción agropecuaria, permitindo a alimentación da poboación que habitara o recinto principal.

Igualmente, obsérvase unha lóxica diferenciada na intensidade defensiva dependendo da zona do recinto, adaptándose con precisión ao terreo natural. A primeira lóxica é aplicábel, principalmente, aos sectores oriental e setentrional. Estas zonas do sistema defensivo cobren as ladeiras do Monte Aloia máis escarpadas que son as de máis difícil ascenso. Polo tanto, nestes sectores non se aplica unicamente unha lóxica defensiva, xa que esta xa se ve reforzada polo medio natural, senón que tamén se busca a inclusión dentro do recinto da maior cantidade de terreo posíbel e un maior número de fontes de auga, en forma de mananciais ou regueiros. Entendemos que esta dupla combinación de factores é o que inflúe no trazado do sistema defensivo que todas as autoras comentan (Blanco-Rotea, 2013: 15-27). A segunda lóxica céntrase na zona occidental e meridional do recinto. Nestes sectores, o principal obxectivo do sistema defensivo é fechar un espazo o máis eficientemente posíbel. Non hai que esquecer que é a zona 


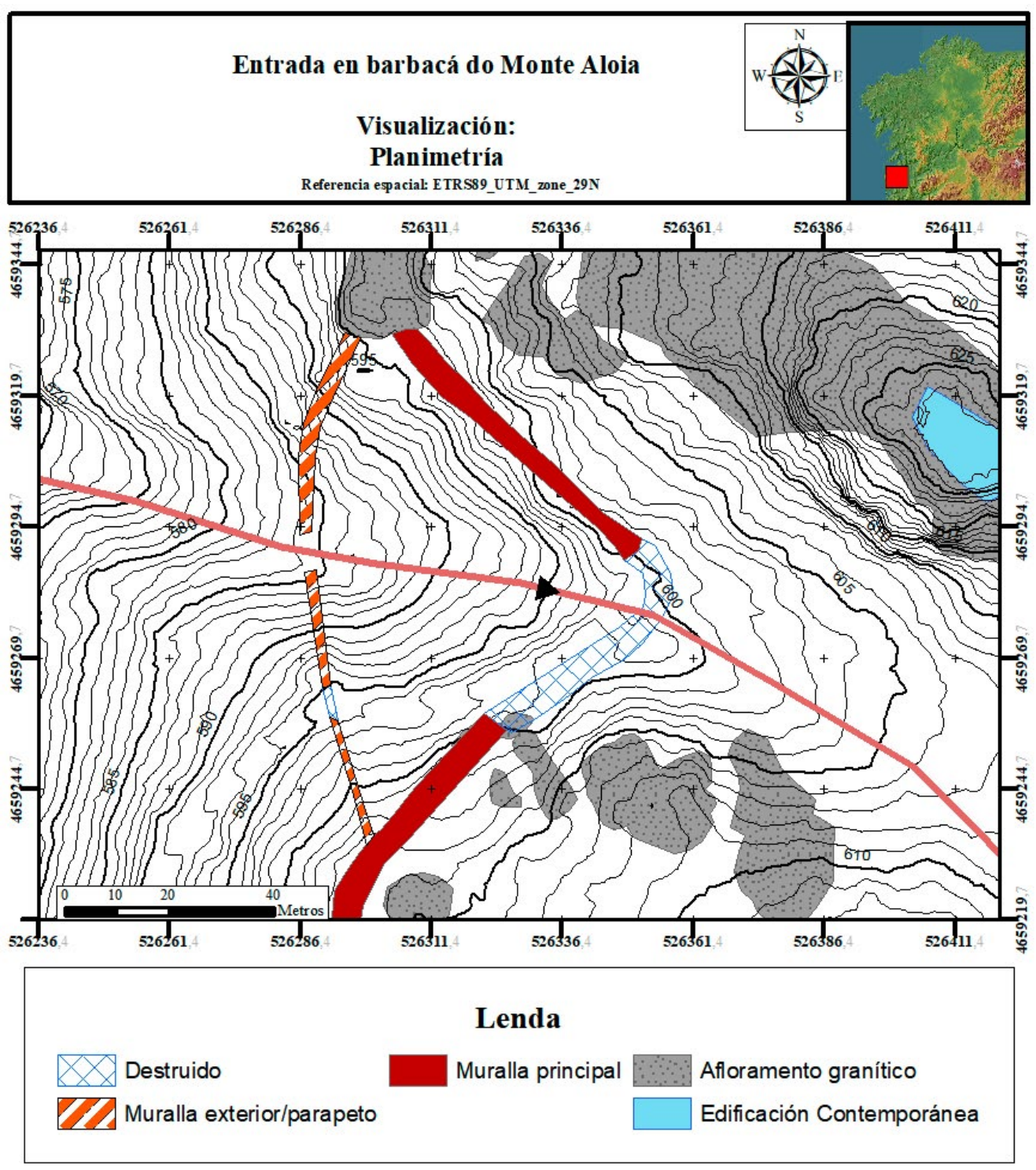

Figura 9: Planimetría detallada da Barbacá. (Figura realizada polo autor)

máis próxima á valgada onde conflúen as dúas vías de acceso principais. Para isto, a súa construción está baseada na adecuación aos desniveis do terreo, na procura dos afloramentos graníticos e elevacións do terreo co fin de obter unha boa posición defensiva e de control da zona circundante. Que todos os afloramentos graníticos existentes neste sector estean incluídos dentro do trazado e poidan funcionar como torres, amais das xa mencionados indicios de dúas torres construídas, non é algo casual. Polo tanto, podemos concluír que a intensidade no esforzo defensivo varía dependendo das necesidades puntuais de cada zona, reforzando con outros elementos construtivos (torres, barbacá etc.) onde for necesario. Malia estas variacións na situación dos elementos defensivos, apenas se documentan variacións representativas no ancho nin na fábrica dos lenzos ao longo de todo o recinto fortificado.

Esta impresión de que o lado occidental do sistema defensivo do Aloia recibe un interese especial no seu esforzo defensivo refórzase coa documentación dunha barbacá (Fig. 9). Esta xa é coñecida dende a planimetría realizada por Garrido (1987: 17). Denominamos baixo este termo ${ }^{12}$ a un lenzo murario de menores dimensións (uns dous metros de ancho, aínda que conserva a mesma fábrica do resto do sistema defensivo) que o principal e que se atopa fechando a valgada que identificamos como de acceso ao interior do recinto. $\mathrm{Na}$ actualidade, a construción dunha pista asfaltada destruíu o punto da muralla principal onde entendemos que se localizaría a porta e tamén un tramo da barbacá. Na intervención do 2001 escavouse a unión dos dous lenzos, podendo identificar como esta última apega á muralla principal.

12. Aínda que somos conscientes que esta tipoloxía construtiva comeza a desenvolverse en grande medida nos castelos medievais pasando o séc. X e. c., suponse a súa orixe nas fortificacións de época bizantina (Gil Crespo, 2013: 152-154). 


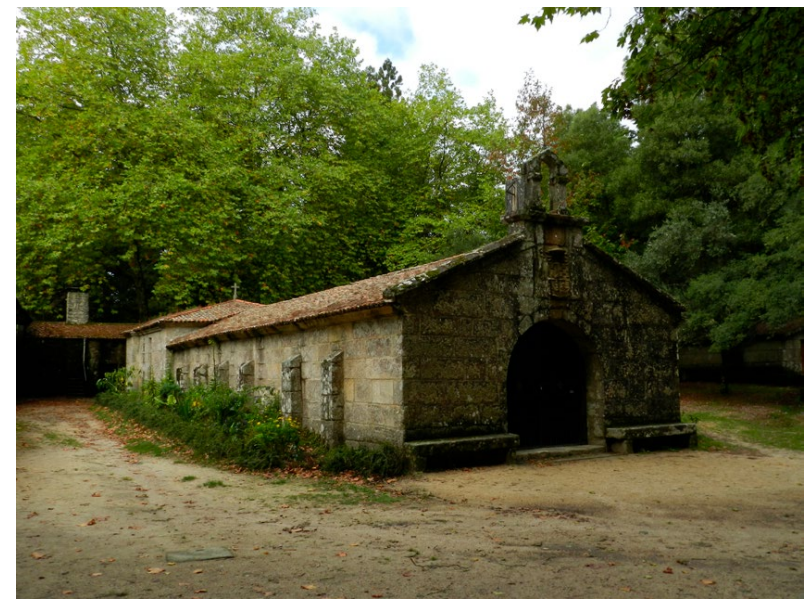

Figura 10: Fotografía da Capela de San Xiao. (Fotografía do autor)

Este sistema bloquea e impide o acceso directo e rápido á entrada, procurando unha defensa en profundidade da mesma. A utilización de torres e entradas complexas permite observa que o equipo construtor do recinto defensivo tiña un coñecemento da arte da fortificación. Amais disto, tamén se observa unha economía nos recursos investidos, xa que realización dun anel murario paralelo (como ocorre noutros sistemas defensivos) precisaría dunha grande inversión e, seguramente, non incrementaría apreciabelmente o esforzo defensivo do recinto fortificado.

Malia ser escavadas até cinco estruturas situadas no interior do recinto, pouco se coñece sobre a súa tipoloxía. A escaseza de datos recollidos no informe valorativo non permite precisar a localización exacta nin planta nin tamaño. A máis característica sería a xa mencionada estrutura teitada de tegulae arredor da Cama de San Xiao, posibelmente construída en materiais perecedoiros e cunha posíbel función relacionada co carácter simbólico-relixioso do afloramento, que entendemos, provén de antigo. $\mathrm{O}$ resto das estruturas localizadas foron exhumadas de modo parcial e con diferentes graos de conservación. No informe non se referencia a súa forma nin se inclúen debuxos ou fotografías da súa planta. $\mathrm{O}$ que si se menciona é o uso de tegula tanto para teitar como a modo de ripios nos muros. Por último, escavouse nas proximidades da Capela de San Xiao (Fig. 10), exhumando un nivel cheo de restos de tégulas anterior a dita construción, elemento que identificou o equipo como o que semella un templo anterior ó actual (Constela Doce, 2001: 14).

\section{INTERPRETACIÓN DO RECINTO DO ALOIA}

Como xa se indicaba ao principio do texto, os datos arqueolóxicos coñecidos a respecto do asentamento fortificado do Monte Aloia son reducidos e/ou parciais. A orixe destes é, en parte, responsábel disto. A ferramenta metodolóxica da prospección arqueolóxica, sexa esta en campo ou a través de medios dixitais, malia ser útil e necesaria para facer esta primeira aproximación ao xacemento, non permite afondar, neste caso, en funcionalidade ou etapas cronolóxicas. Malia ter sido obxecto de varias escavacións arqueolóxicas, o fallo na transmisión dos resultados pola falta de memorias completas provoca que, como xa se ven repetindo ao longo do texto, sexa complexo extraer datos e conclusións concluíntes ${ }^{13}$. Polo tanto, na actualidade, o actual coñecemento arqueolóxico sobre o xacemento do Aloia permite coñecer a planimetría do seu sistema defensivo, mais non do seu interior, por non dicir o arriscado que é formular hipóteses sobre a súa funcionalidade ou cronoloxía.

O xacemento situado no cumio do Monte Aloia é un recinto fortificado dun tamaño extraordinario e pouco común no noroeste peninsular. Neste espazo xeográfico só é posíbel mencionar menos de media ducia de fortificacións que teñan un tamaño semellante: as capitais conventuais de Lucus Augusti -34 ha- (Alcorta Irastorza, 2009) e Bracara Augusta -44-50 ha(Martins et al., 2012; Sande Lemos et al., 1998) ou, no caso de recintos fortificados parecidos ao Aloia ${ }^{14}$, e xa a moita distancia en canto a superficie ocupada, pódense mencionar os casos de Castro Valente - próximo a Iria Flavia, 10 ha- (Fernández Abella, 2014; FernándezPereiro et al., 2017) ou Castro Ventosa-Cacabelos, 5' 5 ha- (Tejerizo-García e Vigil-Escalera Guirado, 2017). Outros asentamentos fortificados en altura comparábeis, aínda que máis distanciados, poderían ser Dehesa de los Olivos -Madrid, 28 ha- (Vigil-Escalera, 2012) ou Peña Amaya -Burgos, 32 ha-(Quintana López, 2017).

A falta de cultura material, que puidera actuar como material datante, non permite realizar unha hipótese de secuencia cronolóxica precisa. O único elemento material que pode indicar unha época é a ampla presenza de tegulae, mencionada en todos os traballos realizados arredor deste xacemento. A tegula, elemento construtivo de orixe romana, ten un abano cronolóxico de utilización dende o cambio de era até o séc. VII-VIII e. c., aproximadamente, sendo incluso posíbeis reutilizacións posteriores (Fernández Mier e Quirós Castillo, 2012; Utrero Agudo e Sastre de Diego, 2012). A partir de aquí só se poden facer especulacións. Se cruzamos os seguintes datos: A) a presenza da tegula, abano do séc. I ao VIII e. c.; B) a mención á antigüidade da civitas do Aloia no documento de restauración da sé do bispado de

13. Malia o carácter fragmentario dos informes depositados, podería ser que o depósito de memorias completas non resolvera as dúbidas expostas neste texto debido á concepción do proxecto orixinal. Polo tanto, sería importante a execución dun proxecto focalizado no xacemento do Aloia, co obxectivo de responder os múltiples interrogantes existentes arredor do mesmo.

14. O seu tamaño, a súa diferenciación morfolóxica cos asentamentos fortificados protohistóricos, o descoñecido da súa secuencia ocupacional ou a materialidade conservada, poden ser factores de similitude co Aloia. 
Tui, aportando unha datación ante quem séc. XI, debido a que nese momento o asentamento xa estaba abandonado; e C) a tradición historiográfica e a investigación arqueolóxica que asume que un recinto fortificado do estilo do Aloia non pode existir baixo o Imperio Romano (Fernández-Pereiro et al., 2017; Gutiérrez González, 2014), post quem séc. V e. c.; é posíbel restrinxir o principal momento de ocupación para o recinto fortificado do Aloia entre os séc. V e VIII e. c., a Primeira Alta Idade Media (Nissen-Jaubert, 2006: 143) ${ }^{15}$.

Dentro desta ampla cronoloxía, e seguindo a historiografía coñecida para este tipo de asentamentos fortificados, poderíamos considerar ao recinto do Aloia coma un 'Castelo de primeira Xeración' (Brogiolo e Gelichi, 1996; Quirós Castillo, 2013b: 308-316). Pérez Losada data a fin da ocupación do aglomerado secundario romano de Tui a inicios do séc. V (Pérez Losada, 2002: 85-86), o que podería indicar que os autores clásicos non estaban desencamiñados cando incidían en que a poboación podería terse desprazado dende o fondo do val ao alto do Aloia. Este posíbel abandono de Tui sería un fenómeno similar ao do abandono das villae e a súa substitución por asentamentos fortificados. Esta ocupación de castros et castella (Gutiérrez González, 2014) está, na nosa opinión, ligada a unha estratexia de control social e territorial por parte das elites locais tardorromanas (Castellanos García e Martín Viso, 2005; Quirós Castillo, 2013a, 2013b; Vigil-Escalera Guirado e Tejerizo-García, 2014). A desaparición do estado romano creou un baleiro de poder aproveitado por estes grupos sociais para procurar obter o poder absoluto e permitir, paralelamente, por exemplo, exercer unha forte resistencia, se seguimos a Idacio ${ }^{16}$, a outras elites (neste caso, as suevas) que pretendían imporse no mesmo espazo xeográfico.

Outra posibilidade sería ligar o asentamento do Aloia coa aparición nos séc. VIII-IX dos 'Castelos de segunda xeración’ (Quirós Castillo, 2013b: 316-332). Estas cronoloxías poderían xustificarse pola reutilización de fragmentos de tegulae como ripio para a construción das estruturas interiores. Este período histórico é aínda máis descoñecido que o do séc. V, mais a ocupación do Aloia se debería, seguramente, á desaparición do estado visigodo e ao control de espazos rexionais por parte das elites locais. A aparición e o posterior establecemento dunha estrutura supralocal (como é o reino dos astures) quitaríalle o sentido a este tipo de asentamentos fortificados. Tampouco é descartábel unha dupla ocupación (séc. V e VIII) como se ven documentando en asentamentos fortificados bastante

15. Existe un interesante debate sobre o modo de denominar este período, que é brevemente abordado por Tejerizo (2017: 35) partindo do proposto por Wickham (2009).

16. Sueui sub Hermerico rege medias partes Callaciae depraedantes per plebem quae castella tutiora retinebat acta suorum partim caede, partem captiuitate, pacem quam ruperant familiarum quae tenebantur redhibitione restaurant. (Idacio, 81, en López Silva, 2004). parecidos como Peña Amaya (Quintana López, 2017) ou Tedeja (Palomino Lázaro et al., 2012).

\section{CONCLUSIÓNS}

A revisión historiográfica, documental e material do Aloia, xunto coas tarefas de prospección, permitiron realizar unha planimetría detallada do sitio, aportando datos inéditos e actualizando a xa realizada por Garrido no 1987. A partir desta, foi posíbel realizar unha serie de análises sobre a arquitectura do lugar, propoñendo hipóteses a respecto das peculiaridades construtivas do recinto. A maiores, a información proporcionada polas varias fontes históricas coñecidas que tratan ou describen o recinto do Aloia permítenos entender como se observaba e incluía na paisaxe a este asentamento fortificado. Con todo isto, e coas limitacións xa mencionadas, consideramos que é posíbel realizar unha proposta de secuencia de ocupación para o asentamento fortificado do Monte Aloia. É preciso entender esta coma unha hipótese preliminar, que é preciso confirmar a través da investigación arqueolóxica, ca fin de completar a falta de datos actuais. A nosa proposta identificaría a este recinto dentro dos fenómenos puntuais do rexurdir da paisaxe fortificada ao longo da Alta Idade Media. As investigacións previas identificaban a ocupación do Aloia entre os sec. V-X e. c. (Garrido Rodríguez, 1987: 14-27; Sánchez-Pardo, 2012), mais nós entendemos que só é posíbel, dentro dese período, que este recinto se ocupara arredor do séc. V ou do VIII-IX e. c. Esta puntualización cronolóxica incide na relación deste tipo de asentamento coa desaparición dun poder supralocal (Imperio Romano ou Reino Visigodo) e a súa relación coa emerxencia dos poderes locais ao longo da Alta Idade Media (Tejerizo-García, 2016).

Polo tanto, como axenda de futuro, sería interesante realizar, dentro do posíbel, traballos arqueolóxicos en profundidade que nos permitan identificar secuencias de ocupación. Estes traballos poderían incluír: A) A exhumación de parte do sistema defensivo ca fin de coñecer as diferentes, de existir, fases construtivas. A lectura de paramentos ou a realización de análises de morteiros e/o sedimentos permitiría afinar as cronoloxías. B) A escavación en área do interior do recinto. Na campaña realizada no 2001 soamente se interveu no interior das estruturas recoñecidas en superficie. Polo que coñecemos, non existiron resultados positivos no achado de cultura material e apenas se avanzou no coñecemento da tipoloxía construtiva. A apertura dunha ampla zona permitiría, en principio, superar estas limitacións e coñecer a distribución interna do asentamento.

Con todo isto, consideramos que os resultados deste traballo poden considerarse un primeiro paso e estimulante de futuros traballos que amplíen información sobre este tipo de asentamentos fortificados e o momento histórico no que se insiren, tras a fin do Imperio Romano de Occidente e a transición política e social da Gallaecia dende unha provincia a un reino. 


\section{AGRADECEMENTOS}

Queremos agradecer a José Carlos Sánchez-Pardo, a Carlos Tejerizo-García e as dúas persoas que revisaron este texto os seus comentarios e aportacións.

\section{REFERENCIAS}

Alcorta Irastorza, E. (2009). La muralla de Lugo. Un ejemplo de ingeniería militar romana bajo imperial. Traianvs, 1-50. Recuperado de: http://www.traianvs.net/

Ávila y La Cueva, F. (1995). Historia civil y eclesiástica de la ciudad de Tuy y su obispado. 1852. Pontevedra: Consello da Cultura Galega.

Blanco-Rotea, R. (2013). Trabajos arqueológicos realizados en el transcurso de la redacción del Plan Director de las Fortalezas Transfronterizas del Tramo Bajo del Río Miño. CAPA: cadernos de arqueoloxía e patrimonio, 22. Santiago de Compostela: CSIC - Instituto de Ciencias del Patrimonio

Blanco-Rotea, R. (2015). Arquitectura y paisaje. Fortificaciones de frontera en el sur de Galicia y norte de Portugal. (Tese doutoral inédita). Universidad del País Vasco - Euskal Herriko Unibertsitatea. Vitoria-Gasteiz.

Brogiolo, G. P. e Gelichi, S. (1996). Nuove ricerche sui castelli altomedievali in Italia settentrionale. Firenze: All'Insegna del Giglio.

Castellanos García, S. (2006). Ofensivas aristocráticas y articulación política en el norte hispano post-romano. En U. Espinosa Ruiz e S. Castellanos García. Comunidades locales y dinámicas de poder en el norte de la Península Ibérica (pp. 141-164). Logroño: Universidad de La Rioja.

Castellanos García, S. e Martín Viso, I. (2005). The local articulation of central power in the north of the Iberian Peninsular (500-1000). Early Medieval Europe, 13, 1-42. DOI: https://doi.org/10.1111/j.1468-0254.2005.00147.x

Constela Doce, X. (2001). Informe valorativo: Sondaxes arqueolóxicas no recinto interior do Monte Aloia, Parque Natural do Monte Aloia. Tui, Pontevedra. Santiago de Compostela: Servizo de Arqueoloxía, Dirección Xeral da Xunta de Galicia.

Currás Refojos, B. X. (2015). Transformaciones sociales y territoriales en la cuenca del Baixo Miño entre la Edad del Hierro y la integración en el Imperio Romano. (Tese doutoral). Universidade de Santiago de Compostela. Santiago de Compostela. Recuperado de: https://minerva.usc.es/xmlui/ handle/10347/11869

Fernández Abella, D. (2014). Castro Valente, una fortificación de control del Río Ulla. En R. Catalán Ramos, P. Fuentes Melgar e J. C. Sastre Blanco (Eds.). Las Fortificaciones en la Tardoantigüedad. Élites y articulación del territorio. (Siglos V-VIII d. C.) (pp. 393-398). Madrid: Ediciones de La Ergástula, S.L.

Fernández Costas, M. (1947). El monte Medulio ¿Es el Monte Aloya? Construcciones. Revista de la Federación Nacional de Aparejadores, 13.
Fernández Mier, M. e Quirós Castillo, J. A. (2012). Para una historia social de la arquitectura monumental altomedieval asturiana. En L. Caballero Zoreda, P. Mateos Cruz e C. García de Castro Valdés (Eds.). Asturias entre visigodos y mozárabes (pp. 27-53). Madrid: CSIC.

Fernández-Pereiro, M. (2016). O Faro de Budiño: Uma outra fortaleza tardoantiga?. En S. Martínez Caballero, V. M. Cabañero Martín e C. Merino Bellido (Eds.). Investigaciones arqueológicas en el valle del Duero: del Paleolítico a la Edad Media. Actas de las IV Jornadas de Jóvenes Investigadores del Valle del Duero 2014 (pp. 349-362). Segovia: Glyphos Publicaciones.

Fernández-Pereiro, M. (2019). Recintos fortificados en altura na costa atlántica galega. Un estudo arqueolóxico. (Tese doutoral inédita). Universidade de Santiago de Compostela. Santiago de Compostela.

Fernández-Pereiro, M., Ferreiro Diz, O., Guillán Armendáriz, A. e Rial Figueiras, M. T. (2017). Arredor da existencia de castra et castella tardoantiguos nas proximidades dos vici galaicos. En A. Álvarez Rodríguez, C. Tejedor Rodríguez e I. García Vázquez (Eds.). Investigaciones arqueológicas en el valle del Duero : del Paleolitico a la Edad Media : actas de las V Jornadas de Jóvenes Investigadores del valle del Duero. Del Paleolítico a la Edad Media (pp. 399-414). Valladolid: Glyphos Publicaciones.

Fernández-Pereiro, M., Tejerizo-García, C., Lixó Gómez, C., Rodríguez González, C. e Carvajal Castro, Á. (2017). Asentamentos fortificados no interior da Gallaecia en época tardoimperial e sueva (séc. IV-VI): Un achegamento a partir de varios casos de estudo. Gallaecia, 36, 129-162. DOI: http://dx.doi.org/10.15304/gall.36.5104

Gago Mariño, M. (2010a). O Monte Aloia: un enigma amurallado de 30 hectáreas. Recuperado de: http://www. manuelgago.org/blog/index.php/2010/03/07/o-monte-aloia-un-enigma-amurallado-de-3200-metros/

Gago Mariño, M. (2010b). Repúblicas de Homes Libres: Aloia, a nova cidade xurdida do medo. Recuperado de: http:// www.manuelgago.org/blog/2010/04/26/republicas-de-homes-libres-aloia-a-nova-cidade-xurdida-do-medo/

Galindo Romero, P. (1923). Tuy en la baja edad media: siglos XII-XV. Suplemento al tomo XXII de la España Sagrada, del p. Flórez. Zaragoza: El Noticiero.

Garrido Rodríguez, J. (1987). Fortalezas de la antigua provincia de Tuy. Pontevedra: Diputación Provincial de Pontevedra.

Garrido Rodríguez, J. (2010). Las murallas del Monte Aloia. A la búsqueda de sus orígenes. Castellum Tyde. Revista do Instituto de Estudios Tudenses, 3, 97-149.

Gil Crespo, I. J. (2013). Fundamentos constructivos de las fortificaciones fronterizas entre las coronas de Castilla y Aragón de los siglos XII al XV en la actual provincia de Soria. (Tese doutoral). Universidad Politécnica de Madrid. Madrid. Recuperado de: http://oa.upm.es/22399/

Gutiérrez González, J. A. (2014). Fortificaciones Tardoantiguas y visigodas en el norte peninsular (ss. V-VIII). En R. Catalán Ramos, P. Fuentes Melgar e J. C. Sastre Blanco (Eds.). Las Fortificaciones en la Tardoantigüedad. Élites y 
articulación del territorio. (Siglos V-VIII d. C.) (pp. 191214). Madrid: Ediciones de La Ergástula, S.L.

Huerta y Vega, F. J. M. de la. (1733). Anales de el Reyno de Galicia. Santiago de Compostela: Imprenta de D. Andrés Frayz.

Lixó Gómez, C. (2018). Os castros nos tempo das villae. Funcións non militares dos castros no val do Sarria na Alta Idade Media. Cuadernos de Estudios Gallegos, 35, 131, 37-72. DOI: https://doi.org/10.3989/ceg.2018.131.02

López Silva, J. A. (2004). A Crónica de Idacio de Limia, Bispo de Chaves. Ourense: Deputación Provincial de Ourense.

Martínez Murguía, M. (1888). Galicia. Barcelona: Establecimiento tipográfico-editorial de Daniel Cortezo y Cia.

Martínez Sigüenza, X. (2003). As parroquias de Tui. Síntese histórica. Revista de estudios provinciais, 19, 11-58.

Martins, M., Ribeiro, J., Magalhães, F. e Braga, C. (2012). Urbanismo e Arquitetura de Bracara Augusta. Sociedade, economia e lazer. En M. do Carmo Ribeiro e A. Sousa Melo (Eds.). Evolução da paisagem urbana. Sociedade e economia (pp. 29-68). Braga: CITCEM.

Nissen-Jaubert, A. (2006). Le haut Moyen Âge. En A. Ferdière, V. Matterne, P. Méniel e A. Nissen-Jaubert (Eds.). Histoire de l'agriculture en Gaule : 500 Avant J-C - 1000 après $J-C$ (pp. 141-197). París: Éditions Errance.

Palomino Lázaro, Á. L., Negredo García, M. J. e Bohigas Roldán, R. (2012). La fortaleza de Tedeja en Trespaderne y el castillo de Poza de la Sal (Burgos). Variables arqueológicas para el análisis de la articulación del poder local en el tránsito de la tardoantigüedad a la Alta Edad media en la Castilla del Ebro. En J. A. Quirós Castillo e J. M. Tejado Sebastián (Eds.). Los castillos altomedievales en el noroeste de la Península Ibérica (pp. 263-290). Bilbo: Euskal Herriko Unibertsitatea, Argitalpen Zerbitzua.

Pérez Losada, F. (2002). Entre a Cidade e a Aldea: estudio arqueohistórico dos «aglomerados secundarios» romanos en Galicia. Brigantium: Boletín do Museo Arqueolóxico e Histórico da Coruña, 13, 15-348.

Prieto Robles, M. S. (2001). Informe valorativo: Acondicionamiento y trabajos previos para la restauración de la muralla del Monte Aloia. Paruqe Natural del Monte Aloia. Tui, (Pontevedra). Santiago de Compostela: Servizo de Arqueoloxía, Dirección Xeral da Xunta de Galicia.

Quintana López, J. (2017). El castro de Peña Amaya (Amaya, Burgos): del Nacimiento de Cantabria al de Castilla. Santander: Instituto de Prehistoria y Arqueología «Sautuola».

Quirós Castillo, J. A. (2013a). Archaeology of power and hierarchies in early medieval villages in Northern of Spain. En J. Klapse (Ed.). Hierarchies in rural settlements (pp. 199212). DOI: https://doi.org/10.1484/M.RURALIA.1.101610

Quirós Castillo, J. A. (2013b). Defensive sites of the early middle ages in North-West Spain. En J. Baker, S. J. Brookes e A. Reynolds (Eds.). Landscapes of defence in early medieval Europe (pp. 27-53). DOI: https://doi. org/10.1484/M.SEM-EB.1.100883

Sánchez-Pardo, J. C. (2010a). Castros y aldeas galaicorromanas: sobre la evolución y transformación del poblamiento indígena en la galicia romana. Zephyrus, $L X V, 129-148$.

Sánchez-Pardo, J. C. (2010b). Los ataques vikingos y su influencia en la Galicia de los siglos IX-XI. Anuario Brigantino, 33, 57-86.

Sánchez-Pardo, J. C. (2012). Castros, castillos y otras fortificaciones en el paisaje sociopolítico de Galicia (siglos IV-XI). En J. A. Quirós Castillo e J. M. Tejado Sebastián (Eds.). Los castillos altomedievales en el noroeste de la península ibérica (pp. 29-55). Bilbo: Euskal Herriko Unibertsitatea, Argitalpen Zerbitzua.

Sande Lemos, F., Martins, M., Fontes, L., Freitas Leite, J. M. e Cunha, A. (1998). A redescoberta da muralha romana e suevica-visigotica de Braga. Forum, 24, 11-25.

Sandoval, P. de. (1610). Antiguedad de la ciudad y iglesia cathedral de Tuy y de los Obispos que se save aya auido en ella: sacada de los concilios y cartas reales y otros papeles. Braga: Imprenta de Fructuoso Lourenço de Basto.

Sandoval, P. de. (1615). Historia de Idacio Obispo, que escrivio poco antes que España se perdiese. De Isidoro Obispo de Badajoz,... De Sebastiano Obispo de Salamanca,... De Sampiro Obispo de Astorga,... De Pelagio Obispo de Oviedo,... Pamplona: Pedro Escuer.

Tejerizo-García, C. (2016). The end of the world as we know it»: post-imperial social landscapes in North-Central Iberia ( $5^{\text {th }}-6^{\text {th }}$ centuries). Archaeologia Medievale, XLIII, 383-397

Tejerizo-García, C. (2017). Arqueología de las sociedades campesinas en la cuenca del Duero durante la Primera Alta Edad Media. Bilbo: Euskal Herriko Unibertsitatea, Argitalpen Zerbitzua.

Tejerizo-García, C., Rodríguez González, C. e FernándezPereiro, M. (e.p.). Observaciones sobre la continuidad de los castros en época tardoimperial y sueva en la Gallaecia: una revisión de la secuencia de ocupación en el castro de Viladonga (Castro de Rei, Lugo). SPAL: Revista de prehistoria y arqueología de la Universidad de Sevilla.

Tejerizo-García, C. e Vigil-Escalera Guirado, A. (2017). Castro Ventosa y la Cabeza de Navasangil: una revisión de sus secuencias de ocupación y del fenómeno de los asentamientos fortificados altomedievales. NAILOS: Estudios Interdisciplinares de Arqueología, 4, 129-161.

Torres Bravo, V. C. (2001a). Informe valorativo: Consolidación do tramo de muralla escavado do recinto fortificado do Parque Natural do Monte Aloia, Tui, Pontevedra. Santiago de Compostela: Servizo de Arqueoloxía, Dirección Xeral da Xunta de Galicia.

Torres Bravo, V. C. (2001b). Informe valorativo: Escavación arqueolóxica dun tramo da muralla do recinto fortificado do Monte Aloia, Parque Natural do Monte Aloia. Tui, Pontevedra. Santiago de Compostela: Servizo de Arqueoloxía, Dirección Xeral da Xunta de Galicia. 
Utrero Agudo, M. de los Á. e Sastre de Diego, I. (2012). Reutilizando materiales en las construcciones de los siglos VII-X. ¿Una posibilidad o una necesidad?. Anales de Historia del Arte, 22, Num. Especial (II), 309-323. DOI: https://doi. org/10.5209/rev ANHA.2013.v23.41575

Vigil-Escalera Guirado, A. (2012). El asentamiento encastillado altomedieval de la Dehesa de la Oliva (Patones, Madrid). En J. A. Quirós Castillo e J. M. Tejado Sebastián (Eds.). Los castillos altomedievales en el noroeste de la Península Ibérica (pp. 239-262). Bilbo: Euskal Herriko Unibertsitatea, Argitalpen Zerbitzua.

Vigil-Escalera Guirado, A. (2015). Los primeros paisajes altomedievales en el interior de Hispania. Registros campesinos del siglo quinto d. C. Bilbo: Euskal Herriko Unibertsitatea, Argitalpen Zerbitzua.

Vigil-Escalera Guirado, A. e Tejerizo-García, C. (2014). Asentamientos fortificados altomedievales en la meseta, algunas distorsiones historiográficas en las fortificaciones en la tardoantigüedad: élites y articulación del territorio (siglos V-VIII d. C.). En R. Catalán Ramos, P. Fuentes Melgar e J. C. Sastre Blanco (Eds.). Fortificaciones en la tardoantigüedad : élites y articulación del territorio (siglos V-VIII d. C. (pp. 229-246). Madrid: Ediciones de La Ergástula, S.L.

Wickham, C. (2009). The inheritance of Rome: a History of Europe from 400 to 1000. London: Penguin. 